\title{
Constructions of Success in Academia: An Early Career Perspective
}

Expectations around success in academia vary, and early career academics often receive conflicting messages about what they should concentrate on to achieve promotion or tenure. Taking a social constructionist approach, this paper considers the constructs of objective and subjective career success in academia and shares the perspectives of early career academics in three countries in relation to these narratives. Key findings are that objective career success in academia dominates the literature but remains ill-defined in the minds of the early career academics to whom the measures are applied, and that subjective career success in academia needs both more research attention and more consideration in promotion, tenure, and workload deliberations and policies.

Keywords: early career academics; objective career success; subjective career success; faculty satisfaction

Published in Studies in Higher Education, online 5 August, 2015, in print 2017. Please cite as: Sutherland, K. A. (2017). Constructions of success in academia: An early career perspective. Studies in Higher Education, 42(4), 743-759.

\section{Introduction}

Early career academics face a ladder of salary scales and a barrage of promotion and tenure committees, before potentially attaining the status of full professor, a position described as 'the peak of an academic career' (Douglas, 2013, 379). In North America, tenure serves as the barrier between limited term lectureships, and job security in a coveted professorial role, while in New Zealand (and most other Commonwealth countries), academics move from lecturer to professor over a long period - if a candidate for professor at my university followed the scales starting at the first lecturer step, it would take at least 23 years to reach full professor.

However, attaining the rank of full professor is just one measure of success in academia. Indeed, many outside the university would not distinguish between a lecturer and full professor (especially when the labels are the same but the timelines and expectations vary worldwide), and many academics themselves have no aspirations to a 
full professorship or chair. What constitutes success for one academic may be low on another's list of priorities. What one university values may not even appear in another's promotion criteria. Success in academia, it would seem, is defined differently at every turn, and yet research on what actually constitutes success in academia is not easy to find. We know that academia has moved toward a more performative culture (Archer 2008; Bostock 2014) where what is able to be measured and counted (numbers of research outputs and citations; h-Index rankings; and student evaluation scores, for example) have become the predominant indicators for success. But we also know that these crude measures of performance offer only one perspective on academic life. Individual academics' aspirations and well-being figure strongly in personal measures of success, but are not given much space in appraisal and promotions systems (Macfarlane 2007), or in the research literature on career success (Dries 2011). Nor are the voices of those at the beginning of their academic careers heard much in this conversation.

This paper offers the findings of a qualitative research project that investigated the experiences of early career academics in three different countries, asking about their own perspectives on success in academia. Within a social constructionist framework, and using career theory as a guide, it provides an early career perspective on objective and subjective career success in academia. Key findings are that the definitions and expectations around objective career success in academia, while apparently welldefined in the literature, remain opaque to new academics who are presented with conflicting messages about what is expected of them in the first few years on the job. Further, in terms of subjective career success, unless we know what early career academics value personally, we will struggle to support them to meet imposed expectations for success and productivity. Their energies will be pulled in too many 
different directions trying to balance potentially conflicting expectations and hopes. Given this confusion, I argue that we need both to make the objective expectations clearer in official documentation and to tell our own subjective 'success' stories more readily and publicly.

\section{What is success in academia?}

A growing body of international literature from a range of different higher education research fields has reported on various aspects of the early career academic experience, from identity development (Archer 2008; Smith 2010) to satisfaction (Bilmoria, Perry, Liang, Stoller, Higgins and Taylor 2006; Machado-Taylor et al. 2014) and productivity (Parker 2008; Williamson and Cable 2003). Some researchers have looked at the factors that affect academic career success (Stupinsky, Weaver-Hightower and Kartoshkina 2014) and the competing expectations that new academics often encounter in pursuit of their career (Meyer and Evans 2005). However, few empirical studies directly consider just what constitutes success in academia.

Stupinsky et al. (2014) summarise the predominantly North American literature on faculty success and identify about ten studies that define success variously as research productivity, teaching success, low stress, job satisfaction, and career commitment. They acknowledge, however, that definitions of success in the literature are inconsistent. In the United Kingdom, a recent publication from the University of Cambridge tells the stories of successful women at Cambridge. The preface emphasises that 'there is no unique path to success; indeed, that success is not a single thing that we can all agree on' (Bostock 2014, 7). A 'traditional' understanding is offered later in the book, which defines success in academia as, 'based almost exclusively on outcomes, such as grants awarded, papers published, reports completed, prizes won, metrics achieved, money saved or departmental systems redesigned' (Bostock 2014, 85). 
Ultimately, the author calls for a broader, more nuanced 'sophisticated and meaningful definition of success' (85).

Careers researchers offer a very useful approach to grappling with defining success in academia, and have identified two constructs: objective and subjective career success. In an analysis of 68 articles on career success, published over an 11-year period (1992-2002), Arthur et al $(2005,183)$ found that $90 \%$ of the articles referred to objective career success, which was most commonly defined in terms of 'advancement along a hierarchy of power or prestige' and measured by criteria such as salary, promotion rate, hierarchical level and/or status, and, in the case of one article on academic careers, research productivity. By contrast, subjective career success was referred to in $78 \%$ of the articles, and was defined most commonly as 'career satisfaction' and as a construct that 'exists only in people's minds' (Arthur, et al, 2005, 183). Only a few studies (Peluchette 1993; Canal-Dominguez \& Wall 2013; Bilmoria et al 2006) have looked at subjective career success in academia. This dearth of literature offering a holistic view of success in academia is not surprising, given that career researchers have acknowledged such a lack in careers research in general (Dries 2011). Careers researchers argue that more research needs to occur on the construct of subjective career success (Arthur, et al, 2005; Dries 2011) in particular, and this paper makes a contribution in that regard. By asking the question, 'How do early career academics describe success?' it investigates both objective and subjective career success in academia, providing an early career perspective on both.

\section{Success as a social construct}

Success is a social construct: no person's character, behaviours, actions or qualities are inherently successful in and of themselves. Rather, success is a label given to various actions (or the outputs of the actions) by others and/or by the person him or herself. As 
communities, we construct success by observing, recording, reifying and embedding various behaviours and expectations as 'successful'. The communities in which we move and work are thus very significant in identifying how success is constructed (and then perceived and enacted). A social constructionist stance recognises that the university is a 'constellation' of communities of practice (Wenger 1998, 127). In these communities, people with similar goals, skills and endeavours engage in shared enterprises and discourses that inspire, shape, define and re-define them and their environments. Thus, learning to be an academic is a process of social and active participation in 'the practices of social communities and constructing identities in relation to these communities' (Wenger 1998, 4). Early career academics belong to, move between, juggle, construct, and are challenged and influenced by various communities simultaneously, from their immediate departments, to the university as a whole, to their international disciplines and the wider academic community. In one day, an early career academic might encounter expectations of success from any or all of these communities, as well as from themselves.

Theories of situated learning posit that people learn on the job, from their peers and superiors, and in mutual engagement with each other and other communities within their organisation. Such theories also assume that individuals, and the communities themselves, have some control over the structure of the institution, in this case the university: 'An organization is...the meeting of two sources of structure: the designed structure of the institution and the emergent structure of practice' (Wenger 1998, 244). In the meeting of these two structures - the university's rules, processes, and buildings, and the academics' communities in which their teaching, research, and service practices occur - lies also the agency of the communities and the individual academics. Thus, success in academia is constructed by the institutional rules, expectations and policy 
manuals, and the ability (and willingness) of individual academics to comply with or resist these structures. But success is also constructed outside of and separate from institutional expectations and discourses; individual academics have their own personal goals, ambitions and focuses, and, for many, success comes from their ability to make these personal goals fit within the institution's expectations, or at least to minimise conflict between the two. The following section of the paper outlines the research I undertook to uncover how early career academics themselves recognise and construct success in academia.

\section{Methodology}

As already mentioned, my research question was, 'How do early career academics describe success in academia?' The importance of hearing the answers to this simple question is well-described in the careers literature: not enough is written on the 'subjective career' construct, and there is a noticeable absence of early career academics' voices in the careers and higher education literature. I chose interviews as a data collection tool in order to dig deeply into what early career academics perceive of as success, to hear directly from them, and allow them to elaborate on their answers. In Arthur et al's (2005) analysis of research on career success, only a couple of the 68 articles referred to academic careers, and 'not one of the 68 articles...involved listening directly to the research subjects or even allowing them to elaborate on their own criteria for career success' (196). This led Arthur and colleagues to ask, 'How can subjective careers be adequately researched when the subjective interpretations of the career actors themselves - apart from their non-verbal responses to a limited set of questionnaire items - are not allowed expression?' (196). This is one of the key gaps that my paper aims to fill. Furthermore, using interviews is a research approach that fits with a social 
constructionist methodology and provides space for contestations, as well as constructions, of perceived success in academia. It is a method that, as Cohen, Duberley and Mellon $(2004,10)$ have argued, brings 'contradictions and struggles over meaning to the surface... so that we can get beyond the reductionist thinking so prevalent in career theorising'. Two constructs from career theory (objective and subjective career success) thus informed the phrasing of two key interview questions relating to academic career success:

(1) You were nominated for this project as a successful early career academic. Why do you think you have been described that way? [Objective career success]

(2) What does success mean to you, personally, in terms of your academic career? [Subjective career success]

\section{Data collection}

Sixty successful early career academics participated in semi-structured interviews in Canada $(n=16)$, New Zealand $(n=26)$, and Sweden $(n=18)$. Participants came from 11 different universities, and had diverse disciplinary backgrounds: Science (33\%), Arts/Humanities (22\%), Commerce/Law (17\%), Social Sciences (15\%), Health Sciences $(13 \%)$. Ninety two per cent of them were between $30-44$ years old, and $54 \%$ were female. For the purposes of the project, I defined 'early career academic' as being within seven years of having obtained a $\mathrm{PhD}$ and/or having been appointed to their first academic position. The criteria for success were based on a review of the literature, an investigation of promotions documents at eight different universities, and a pilot project in two New Zealand institutions that sought to identify how some early career 
academics constructed their notions of success (Sutherland and Petersen, 2010). The criteria were thus as follows:

- received a research and/or teaching award

- generated significant amounts of external research grant funding

- received early promotion or tenure

- gained a high grade in any external performance scale (such as the Performance Based Research Fund (PBRF) in NZ)

All of the interviewees met at least two of these criteria, with the majority fitting three or four. Participants for the project were chosen from a list of nominees provided at each university by deans, heads of departments, and/or academic development unit directors. At each university, I emailed a representative sample (in terms of disciplines and sex), to seek their involvement in the project. All of those emailed agreed to be interviewed, although three of the interviews had to be conducted over the telephone because timing did not work out for a face-to-face interview. Two of the interviews involved two participants each. The interviews were most commonly conducted in the participants' own office (three over the telephone), and lasted 50-100 minutes. All interviews were audio recorded, and later transcribed verbatim by a research assistant. Participants were sent their transcribed interviews for checking and given the opportunity to amend, clarify and/or add to the transcript as desired. Three added extra comments in the form of an extra paragraph or two in their covering email, and two asked for sections of the transcript that contained sensitive material about or commentary on colleagues to be deleted, which was done before coding began. 


\section{Data analysis}

To start, I took an inductive approach to data analysis, allowing themes to emerge from the data. The constructs of objective and subjective career success then served as an analytical framework that provided a priori codes for a thematic analysis (Braun and Clarke 2006). After coding about 20 of the interview transcripts, I reached saturation point in terms of the generation of new codes, and I then used the over-arching themes of objective and subjective career success (with the corresponding sub-categories that were generated inductively) as codes for the analysis of the remaining 30+ interviews. Braun and Clarke (2006) warn that thematic analysis, wrongly done, can become mere “"anecdotalism”... where one or a few instances of a phenomenon are reified into a pattern or theme, when it or they are actually idiosyncratic' (95). To avoid such anecdotalism, I went back over all transcripts after the initial coding process had generated the sub-categories and confirmed the themes. I determined the prevalence of key categories by counting how many respondents mentioned these categories, and also how many references to each category appeared across all transcripts (some respondents mentioned each category more than once, others not at all). I also asked a colleague who had been involved in the research design process to code three transcripts and when we compared our analyses, we achieved $87 \%$ inter-rater reliability (that is, $87 \%$ of the time we had assigned the same codes to the same text). We discussed where our differences lay, refining the sub-categories through mutual agreement, and the next coding of three more transcripts brought $92 \%$ inter-rater reliability, with which we were confident we had a reliable set of themes. Table 1 provides an overview of the key themes and subcategories. For the purposes of space in this short article, I have only included themes that 15 or more respondents talked about. 


\section{Findings}

In Table 1, the first column lists the themes around objective career success in academia, which primarily come from the answers that people gave when asked why they thought others considered them to be successful. The second column represents subjective career success in academia, which come from respondents' answers to the question about what success meant to them personally.

The key themes are listed in order of popularity among interviewees, and the sub-categories within each theme are also listed by how common it was for interviewees to talk about these issues. For example, 'research productivity' was the most talked about theme in objective career success, and within that theme 'external grant funding' and the 'number of publications and citations' were mentioned most often. For subjective career success, the overall theme of 'freedom' generated more comments than the theme of 'job satisfaction', and 'choosing one's research direction' was considered more important than 'teaching in one's speciality area,' for example. However, it is important to note that all sub-categories represent the views of at least a quarter of interviewees. That is, themes that were mentioned by fewer than 15 interviewees do not appear in this table, so these themes should all be considered as important to early career academics. To maintain confidentiality, when interviewees are quoted in this paper they are identified by a pseudonym, their country and their broad subject area, only.

[Insert Table 1 here] 


\section{An early career perspective on objective career success in academia}

\section{Status}

Objective career success in academia mirrors objective career success in other career arenas in that status, promotion and tenure feature prominently. In academia, 'status' appears to relate most particularly to reputation within one's discipline , including invitations to serve on editorial boards, to give keynote addresses, and to collaborate with others on international research projects. Being asked to take on leadership responsibility within one's department (as a programme director or head of department) or within the university (as chair of an important committee) for example, also generates status for academics (even amongst academics still early in their careers), but such responsibility is not always a desirable status, as Julz describes: 'it's about being on committees, it's about being the head of department, it's about possibly not being the pro-vice-chancellor, because that really is an admin job' (Julz, Science, NZ). The implication here is that doing this kind of administrative work, while it might come with a form of status, really detracts from the 'real' academic work of research and teaching. Early career academics recognise the need for this work nonetheless: 'it's all tradeoffs...somebody has to do these things and so at some point, it has to be you.' (Heather, Science, NZ)

\section{Promotion and tenure}

Promotion and tenure also featured prominently in my interviews, particularly early promotion or tenure, with 33 out of 60 interviewees identifying such rapidity as one of the key reasons why they might be viewed as successful: 'if I focus on teaching, that will actually make me less attractive as a professor than if I focus on the research,

and that's a fact' (Harald, Health Sciences, Sweden). However, the majority (32/60) of 
my interviewees were adamant that promotion and tenure are not possible if one is not also a dedicated academic citizen and teacher: 'teaching and research are equally valued here. You can't be a bad teacher and be successful here' (Darcy, Social Sciences, Canada). These respondents speculated that while their research productivity may have driven decisions to promote them more rapidly or grant them early tenure, their teaching and service were also important components of their being viewed as successful. They (and others) considered themselves to be 'all-rounders' as outlined below in Debbie's comprehensive summation of her success:

'My publication record is pretty good. I've had two papers published in Science, I published first-authored papers in most of the major journals in my field since I've been here, my graduate students have been doing well, and I get teaching evaluations that are about a standard deviation above the mean in my department.' (Debbie, Science, Canada)

Very early in the academic careers of those I interviewed, before the kinds of feats that Debbie outlines would be possible (having successful graduate students, for example, requires some length of time in the role), several interviewees (15) indicated that success is, simply, securing a permanent and/or full-time academic position (as opposed to successive post-docs, research or teaching fellowships, or short-term contracts or part-time roles at several institutions.) With the rates of casualised appointments in universities consistently increasing worldwide, this may well become a marker of success for academics at any point in their career.

\section{Salary}

Salary, however, did not feature highly as a marker of objective career success in academia among my interviewees' responses. When mentioned, it was primarily to note that academia provided them with an adequate, though not stellar, income. Only one interviewee (who had come from working in a church into academia) considered 
the salary as any sort of marker of success: 'It's twice the average salary! So I don't feel like I'm badly paid. I feel remunerated well' (Charles, Humanities, NZ). By contrast, many more (16) interviewees (especially those from the sciences and professional disciplines) noted that they could earn much more outside the academy, and they were not in academia for the money: 'I know that I could get at least $\$ 10,000 \mathrm{KR}$ better just for moving to a company and not even a top position' (Sonia, Commerce, Sweden).

Some interviewees (15) expressed consternation that universities did not recognise success more often by rewarding academics with individual salary increases, particularly when they had been successful at generating significant external funding: 'I don't think it's unreasonable if I'm bringing in a million dollars of grants, that I'm paid 10 percent of what I bring in, but in reality I will be paid less, which I find financially frustrating' (William, Science, NZ). So, while salary does not feature prominently as a marker of success in academia, the generation of funds from outside the university does, and this is a key feature of the first of my objective career success themes that is particular to the academic career: research productivity.

\section{Research productivity}

Research productivity was identified by my interviewees as the key 'objective' criterion upon which they are appointed, promoted, awarded, rewarded and considered successful. Sub-categories within this theme give us some insight into what early career academics consider constitutes research productivity and what they think their superiors and those in charge of promotion decisions view as markers of successful researchers. In particular, getting external grant funding featured very prominently (38 out of 60 interviewees mentioned this theme): 
know that this is more or less the only instrument by which they judge you as a scientist and you need that to get money. So, it's not always to publish that is the issue itself, but it's an issue to get future grants.' (Gunnar, Science, Sweden)

Publishing generates citations, profile, and disciplinary reputation which in turn generate the probability of further research funding, thus creating what has been referred to as the 'Matthew effect' in academia (Merton, 1988) - from the biblical verse (Matthew 13:12), 'For to the one who has, more will be given'. Interviewees commented that what mattered most seemed to be how many publications, in which outlets, not necessarily what was written or what changed as a result of the work. Similarly, for teaching, what counts in an objective career sense is what is actually able to be counted: teaching evaluation scores, and teaching large numbers of students.

\section{Teaching performance}

My interviewees acknowledged that 'excellent' teaching alone would not lead to promotion or tenure, and that research productivity needs to be accompanied by at least 'adequate' teaching. However, what constitutes 'excellent' or 'adequate' teaching is illdefined for many early career academics. The most commonly mentioned criteria were teaching evaluation scores (16/60) and numbers of students (15/60). For example,

Debbie earlier mentioned receiving teaching evaluation scores that were 'a standard deviation above the mean', while Kevin (Commerce, NZ) indicated that being assigned the important classes with big numbers of students was a marker of his teaching success in others' eyes. While the measurements themselves may be unclear (more on this later), what is clear is that objective career success in academia revolves around those aspects of academic life that are countable - the number of publications and citations, external grant funding generated, scores on student evaluations - or that involve external validation - invitations to speak or serve, awards and acknowledgements 
received. In contrast, subjective career success in academia is much less about others measuring one's performance, and much more about personal values and aspirations.

\section{Subjective career success in academia}

The subjective view of career success differs from the objective view in that it is selfdefined rather than externally defined, less easily captured in promotions documents, and often not spoken of, written about, or researched in-depth.

'Life' success and satisfaction are often very closely related to the individual academic's perception of their ability to balance their working life with their family life. But, balance is also required and/or sought in several other facets of an academic's life: between teaching and research, students and colleagues, department and university, grant funder and public, institution and discipline, for example. Not all of these are simple or immutable binary relationships, of course, but all contribute to an academic's perception of balance and ultimately of satisfaction and success.

\section{Job and life satisfaction, and contribution to society}

Life satisfaction featured most prominently in my interviews, followed closely by making a contribution to society, which in academia includes shaping or moulding one's disciplinary area, and changing communities through one's research and teaching. Anand describes below how he refuses to let objective career success measurements define his direction, with subjective career success criteria such as a healthy and happy family, a balance between time spent at work and time spent with family, and making a difference to society, ultimately being more important than the number of publications or receiving good teaching evaluation scores:

'I haven't sacrificed my integrity, my ethics and my work/life balance. It's one thing to dedicate yourself to your career and altogether ignore your children in your pursuit of that. Ultimately, it doesn't resonate, because on the one hand you want to make the world a better place for them, but then you're neglecting them.' (Anand, Health Sciences, Canada) 
Job satisfaction for early career academics involves not so much receiving awards or good teaching evaluations or bringing in lots of external grant money or increasing one's impact factor (all measurable objective academic success markers), but rather receiving positive feedback from students and colleagues, or feeling that one has made a mark or contributed to one's field in some significant way:

'You have your usual indicators like publications and getting grants and stuff, but I think somehow moulding your field is a really important indicator of success, that you've had some kind of influence on how things have developed.' (Aroha, Social Sciences, NZ)

It also means a growing sense of confidence, especially for those early in their careers.

For some, it also means not feeling like failure or a fake:

'I grow more confident and in some situations I feel that I have things to say that really give new ideas to the other researchers...but other days I think, oh, they are going to see who I am, they're really going to see me, that I'm just a fake.' (Frida, Social Sciences, Sweden)

Two other subjective career success themes that may be unique to the academic career came through quite strongly in my interviews: freedom, and influencing students.

\section{Freedom}

Academia is known for flexible workplaces and the freedom that individuals have to choose their focus, direction and, in part, their tasks and duties, as Fran describes below:

'It is completely up to me how I organise and manage my time, so if I turned up in my grandma's nightdress and worked through the night over the summer, no-one would even vaguely give a toss, as long as I fulfilled the things that I have to do. And I like that as a work ethic.' (Fran, Commerce, NZ)

But there are many other kinds of freedom that represent success for early career academics. For many of my interviewees (31/60), subjective career success in academia is marked by having gained the freedom to choose which classes to teach, when, to whom, and at which levels (the smaller - usually - postgraduate and higher-level 
undergraduate classes were the most favoured among my interviewees); which topics to teach (being able to teach a course/s in one's own research area, rather than teaching only survey or introductory courses, for example); and which research to do and with whom (being able to choose your own postgraduate students, to choose to work interdisciplinarily and collectively, and to decide on the research direction for the team/ oneself). The freedom that comes from research success in academia also means that, having proved oneself objectively as a researcher and/or as a consistent generator of external grant funding, one then has the autonomy to make choices about future work:

'I've really got nothing but positive feedback that okay, if you're publishing in Science, do what you want to do. I can do what I want to do and what I think is going to work for me and no-one tries to tell me that's not the way to go.' (Debbie, Science, Canada)

Conversely, if one is not publishing enough or bringing in enough research income, there is a sense that one's freedom will be well and truly curtailed:

'If you're not doing enough research, you'll end up doing more teaching, you'll end up doing more of the dull teaching - whereas I get research grants which pay for somebody else to do my teaching, and I essentially get to choose which bits of my teaching I do. And I go, 'I'll have the fun bits please".' (Julz, Science, NZ)

Being able to choose what one teaches - what, when and to whom - varied for different interviewees. A handful (4) wanted to shed themselves of all teaching responsibilities to focus solely on their research, while others (12) favoured teaching more but within one's research area, and still others (16) wanted to increase the numbers of postgraduate students they were teaching, supervising and influencing. All interviewees saw teaching success in academia as relating to having had a positive influence on students, at all levels. 


\section{Influence on students}

Getting good teaching evaluation scores may be the key measure of objective teaching success in academia, but most (33) of my interviewees expressed more desire to change their students' lives than simply get good teaching evaluations or be the popular teacher. Anand talks about his influence on students being far more important and, to him, a more significant indicator of success, than objective measures such as external grant revenue:

\footnotetext{
'You work hard, and you do things not because you want to be successful; you do things because they're important....If I were to look back 25 years from now, and those students I've taught can say, "Working with him has enabled me to make a better contribution; it's enabled me to get a better sense of my own priorities and my own goals in life and how those goals are going to contribute to the common good and my own wellbeing," I think that would be a good sign of success. Not that I was able to bring in a million dollars.' (Anand, Health Sciences, Canada).
}

Many other interviewees (19) also expressed a desire to teach in ways that allowed students to change their own and others' lives, as well as to move on to successful careers themselves. Several interviewees (15) spoke of producing 'grandchildren' for their academic supervisors, that is, going on to supervise students in the same topic or research team in which they had been supervised themselves: 'We just dedicated our book to this professor, and he used to say, "You're really successful as an academic, when you've grandparented: when your students mentor other students, who get jobs' (Kirsten, Humanities, NZ).

This was a common theme across all disciplines and both sexes. More than half of the women interviewed took this idea even further, explaining that career success for them involved inspiring and opening doors to academic (and other) careers for female students to whom they saw themselves serving as role models. Other interviewees - not a majority, but both indigenous and non-indigenous - felt that career success also involved influencing and inspiring indigenous students, and increasing the numbers of 
indigenous students (and future colleagues) in academia. These kinds of markers of success tend not to be captured in promotions documents or listed in tenure requirements, but it is clear that they carry significant weight for early career academics, and are the gauge by which they judge their success, personally. But, such measures will not see an academic swim to the top of the professorial pool ${ }^{1}$. Early career academics must navigate such waters using the objective career success markers. What happens, though, when those markers are not clear?

\section{Decoding conflicting messages and expectations about success}

'It's kind of a mystery when you come up for tenure... There's lots of gossip that: "So and so got tenure and only had three publications" - "No, you have to have five" - "Oh, no, you have to have seven". Nobody will say exactly how many publications you have to have, but I think that they expect probably about 30 or 40 percent of your time to be done on research, I'm assuming.' (Sarah, Social Sciences, Canada)

As Sarah stresses, early career academics know they have to be productive researchers in order to gain tenure, but she, like many others, is not clear what constitutes 'productivity'. The actual numbers of publications expected, the actual teaching evaluation scores required, the number of citations considered adequate, none of these are obvious. Salena has an even more cynical attitude towards the supposedly objective expectations that people hear promulgated through policy documents and in messages received from managers:

'The politically correct answer is one third research, one third teaching, one third service, right? The more realistic expectation is "as much research as you can do, as much as teaching as you need to, and as little service as you can get away with".' (Salena, Science, Canada).

\footnotetext{
${ }^{1}$ This metaphor is not as perverse as it may first appear: at my university, adjunct, assistant and tutoring staff are referred to as the 'sub-lecturer pool.'
} 
Comments like Salena's imply a lack of trust in the documents that represent the objective career measurements, such as promotion and tenure requirements. If the criteria or expectations were straightforward, the interviewees might use language such as, 'The criteria specify...' or 'The guidelines state...' but instead they use phrases like, 'My impression of the guidelines' (Tim, Science, NZ ) and 'There's certainly a perception' (Oliver, Science, Canada) and 'I have seen it discussed that you should spend a third of your time on teaching, a third on research and a third on sort of admin' (Sydney, Law, NZ). This narrative implies a gap between the guidelines and the reality, or at least that there is another layer of interpretation the academic has to unravel to determine the reality:

'I kind of got conflicting information actually. A lot of people said, "Just go for the research; it's all about research." And then when I looked at the forms and the guidelines, that isn't the impression you get; it's equal teaching, research and service.' (Tim, Science, NZ)

The other challenge, besides working out what the objective requirements actually are, is for early career academics to weigh up the many messages they receive and find a way to balance their personal aspirations with the objective expectations:

\footnotetext{
'It's difficult, because I really like teaching and I think it's a very valuable thing to do. And sometimes you wonder about your articles, like who's going to read them and who cares? Whereas teaching is a very flexible thing; you're teaching other people what you know and then they can do something with it. So it feels more useful in a way. On the other hand I know that within academia it's still very important to publish....people do count your publications more.' (Karin, Social Sciences, Sweden)
}

\section{Discussion}

My research confirms the key themes that come through in the careers literature around objective career success (status, promotion and tenure, and salary) and adds two new themes specific to the academic career (research productivity and teaching performance). It also agrees with earlier careers research on subjective career success 
(job and life satisfaction, and contribution to society) and adds two new themes from academia (freedom and influencing students' lives).

Research productivity was identified by my interviewees as the key 'objective' criterion upon which they are appointed, promoted, awarded, rewarded and considered successful, and the higher education literature reinforces this finding (Enders and Kaulisch 2006; Jepsen, Varhegyi and Edwards 2012; Williamson and Cable 2003). While other elements of the academic role, such as teaching, are considered important, and may be well-rewarded at different phases in the career, the higher up the ranks of academia that academics move, the more they are required to demonstrate research excellence, with unequal regard for other aspects of the academic role (Parker 2008).

Teaching (Jepsen et al., 2012, Parker 2008) and service (Macfarlane 2007) do not appear to be considered as predominant markers of objective success in academia. Academics are expected to be competent in teaching (Adcroft and Taylor 2013) demonstrated, usually, through receiving adequate scores in end-of-term teaching evaluations from students and/or colleagues - and to at least make a show of engaging in university and community service (Smith, Else and Crookes 2013), but neither activity will ultimately lead to senior-level promotions except in all but a few teachingfocussed institutions or at some universities that have introduced teaching paths to professorship (Mackenzie, et al., 2010), although these are often considered 'secondclass' career paths (Fogg 2004). This validation of research success as the key form of success in academia causes consternation and confusion for many early career academics, all of whom harbour personal aspirations for changing students' lives through their teaching, but who may have received different messages about the value 
of teaching and other activities during their graduate school experience. Furthermore, my research shows that early career academics absorb these messages about objective career success and aspire to meet externally imposed expectations around research output and teaching evaluation scores, but that they are often confused about what exactly they need to do in order to demonstrate such achievement.

Expectations around objective career success in academia are laid out in promotions documents and handbooks, but, as my findings show, are lacking in specificity, and open to broad and differentiated interpretation depending on, for example, one's discipline, department, colleagues, and years of experience. Promotions documents and handbooks for early career academics are clear on the areas required to do well, but not clear about how much, how often, for whom and when. In the parlance of the communities of practice literature, the rules tend to be made by the 'old-timers' (Wenger, 1998, p. 153) within the communities and/or stored in peoples' memories rather than on paper, so new academics often find it hard to identify, let alone interpret, what exactly they need to achieve in order to succeed. Wenger (1998) has described this experience for newcomers to a community as a lack of competence along three dimensions: '[not knowing] how to engage with others... not understand[ing] the subtleties of the enterprise as the community has defined it... [and] lack[ing] the shared references that participants use' (1998, p. 153). The artefacts that might help new academics to understand academic success and promotion expectations are often private (others' promotion applications, for example) and the stories of old-timers' personal journeys towards success in academia (with concomitant failures along the way) are not told very often or publically in academia. Failure and rejection, while common to the academic experience, are not spoken of or written about often enough (Peseta 2007). 
Nor is it always clear to new academics that different pathways are possible, depending on which communities (disciplinary, institutional, personal) the individual might choose to prioritise at what point in their career.

It seems that not only do early career academics need clearer guidelines and more specificity in promotion and tenure documentation, they also need more senior colleagues to help them unravel objective expectations about success by talking more about their own personal goals and how they reconciled those with the institution's expectations. As Dries $(2011,380)$ has argued, 'oppressive power structures affecting the enactment of careers can be countered, albeit very gradually, by establishing alternative career discourses between people in everyday life and in the various media (e.g. by propagating different types of "hero stories").'

Furthermore, what the various communities that constitute academia have defined as objective career success is, as my research has shown, not what early career academics perceive of as success for themselves, personally. Peluchette (1993) described the subjective view of career as 'how a person feels about his or her career accomplishments' (198, my emphasis). Careers researchers have recognised over the last couple of decades that how people perceive their career success and the feelings and meaning they attach to it can influence whether they choose or are able to meet externally-imposed standards for success (Dries 2011). Thus, even though a person may appear (as all of my interviewees did) to tick the boxes in terms of external or objective measures of success, if they feel like an impostor, over-worked, under-rewarded, dissatisfied, or imbalanced, they may not continue to achieve such standards regularly 
or consistently, and may also decide to leave the workplace or abandon that particular career.

\section{Conclusion}

The small number of participants from each university and country, and the fact that they were a purposive sample of successful early career academics, mean that the results of this study are obviously not generalisable to all early career academics worldwide. Furthermore, space constraints preclude a comparative analysis of responses from different countries, disciplines, sexes, ages or universities, all of which would be fascinating to see in any future work in this area. Despite these limitations, the stories told by all 60 participants were remarkably consistent in their overall message about the early career academic experience of and perspective on success, and these stories fill a gap in the literature on both objective and subjective career success in academia. There is agreement with the careers literature on what constitutes objective career success (status, promotion, and salary) but research performance is ultimately the key objective measure of success in academia. Early career academics also agree that subjective career success is about life satisfaction and making a contribution to society, but also about freedom and influencing the lives of students.

It is also important to emphasise in closing that there is considerable murkiness around success in academia. If these successful early career academics struggled with the opaqueness of the expectations, then clearly we need to make the various stories of success more transparent in order for all early career academics to navigate healthy, desirable and sustainable pathways into and through academia. Success in academia is not an immutable fact or tangible reward. Rather, 'success,' both objective and subjective, is constructed by academic communities and the individuals within those communities. Objective career success in academia is system-based, measurable, 
countable and public, but also, as my research has shown, lacking in specificity. The narratives that dominate the discourse around objective career success in academia are also externalised by the individual academics: they tell us that, people have said, the university expects us to, and so on. The subjective construction of success, on the other hand is malleable, but private, and often in conflict with the objective expectations. Neither construct is talked about enough in academia; we need to tell more stories of different kinds of success and in different ways. Finally, we need to clarify objective career success expectations at early stages, allowing early career academics the opportunity to influence policy and practice, and be proactive about changing the systems with which they might not be satisfied and from which they may, if we are not attentive to their needs, walk away.

\section{References}

Adcroft, A. and D. Taylor. 2013. "Support for New Career Academics: An Integrated Model for Research Intensive University Business and Management Schools." Studies in Higher Education 38 (6): 827-940.

Archer, L. 2008. "Younger Academics' Constructions of 'Authenticity', 'Success' and Professional Identity.” Studies in Higher Education 33 (4): 385-403.

Arthur, M.B., S.N. Khapova and C.P.M. Wilderom. 2005. "Career Success in a Boundaryless Career World." J. Organiz. Behav. 26: 177-202.

Bilmoria, D., S. Perry, X. Liang, E. Stoller, P. Higgins and C. Taylor. 2006. "How Do Female and Male Faculty Members Construct Job Satisfaction? The Roles of Perceived Insitutional Leadership and Mentoring and Their Mediating Processes." Journal of Technology Transfer 31, 355-365.

Bostock, J. 2014. The Meaning of Success: Insights from Women at Cambridge. Cambridge: Cambridge University Press.

Braun, V. and V. Clarke. 2006. "Using Thematic Analysis in Psychology." Qualitative Research in Psychology 3: 77-101.

Canal-Dominguez, J. and A. Wall. 2013. "Factors Determining The Career Success Of Doctorate Holders: Evidence From The Spanish Case." Studies in Higher Education. DOI:10.1080/03075079.2013.806464.

Cohen, L., J. Duberley and M. Mellon. 2004. "Social Constructionism in the Study of Career: Accessing the Parts That Other Approaches Cannot Reach." Journal of Vocational Behavior 64: 407-422.

Douglas, A.S. 2013. "Advice From The Professors in a University Social Sciences Department on the Teaching-Research Nexus." Teaching in Higher Education, 18 (4): 377-388. 
Dries, N. 2011. "The Meaning of Career Success: Avoiding Reification Through a Closer Inspection of Historical, Cultural, and Ideological Contexts." Career Development International 16 (4): 364-384.

Enders, J. and Kaulisch, M. 2006. "The Binding and Unbinding of Academic Careers." In The Formative Years of Scholars, edited by U. Teichler, 85-96. London: Portland Press.

Fogg, P. 2004. "For These Professors, 'Practice' Is Perfect." Chronicle of Higher Education 50 (32): A12-A14.

Jepsen, D., Varhegyi, M., and Edwards, D. 2012. “Academics' Attitudes Towards Phd Students' Teaching: Preparing Research Higher Degree Students for an Academic Career.” Journal of Higher Education Policy \& Management 34(6): 629-645.

Macfarlane, B. 2007. The Academic Citizen: The Virtue of Service in Academic Life. London and NY: Routledge.

Machado-Taylor, M.L., V.M. Soares, R. Brites, J.B. Ferreira, M. Farhangmehr, O.M.R. Gouveia and M. Peterson. 2014. "Academic Job Satisfaction and Motivation: Findings from a Nationwide Study in Portuguese Higher Education." Studies in Higher Education, DOI: 10.1080/03075079.2014.942265.

Mackenzie, J., S. Bell, J. Bohan, A. Brown, J. Burke, B. Cogdell, S. Jamieson. 2010. "From Anxiety to Empowerment: A Learning Community of University Teachers." Teaching in Higher Education 15 (3): 273-284.

Merton, R.K. 1988. "The Matthew Effect in Science, II: Cumulative Advantage and the Symbolism of Intellectual Property." ISIS 79(4): 606-623.

Meyer, L., and Evans, I. 2005. "Supporting Academic Staff: Meeting New Expectations in Higher Education without Compromising Traditional Faculty Values." Higher Education Policy 18: 243-255.

Ng, T.W.H., L.T. Eby, K.L. Sorensen, and D.C. Feldman. 2005. "Predictors of Objective and Subjective Career Success: A Meta-Analysis." Personnel Psychology 58: 367-408.

Parker, J. 2008. "Comparing Research and Teaching in University Promotion Criteria." Higher Education Quarterly 62 (3): 237-251.

Peluchette, J. 1993. "Subjective Career Success: The Influence of Individual Difference, Family, and Organizational Variables." Journal of Vocational Behavior 43(2): 198-208.

Peseta, T. 2007. "Troubling our Desires for Research and Writing within the Academic Development Project." International Journal for Academic Development 12 (1): $15-23$.

Smith, J. 2010. "Forging Identities: The Experiences of Probationary Lecturers in the UK." Studies in Higher Education 35 (5): 577-591.

Smith, K., F. Else and P.A. Crookes. 2014. "Engagement and academic promotion: a review of the literature. Higher Education Research and Development 33 (4): 836-847.

Stupinsky, R.H., M.B. Weaver-Hightower and Y. Kartoshkina. 2014. "Exploring and Testing the Predictors of New Faculty Success: A Mixed-Methods Study." Studies in Higher Education DOI:10.1080/03075079.2013.842220.

Sutherland, K., and Petersen, L. (2010). "The Success and Impact of Early Career Academics in Two New Zealand Tertiary Institutions." Wellington: Ako Aotearoa. https://akoaotearoa.ac.nz/ako-hub/ako-aotearoa-centralhub/resources/pages/success-and-impact-early-career-academics-two-new-z 
Wenger, E. 1998. Communities of Practice: Learning, Meaning and Identity. Cambridge: CUP.

Williamson, I. O., and D. M. Cable. 2003. "Predicting Early Career Research Productivity: The Case of Management Faculty." Journal of Organizational Behaviour 24: 25-44. 
Table 1: Constructions of academic career success, as perceived by early career academics

\begin{tabular}{|c|c|c|c|}
\hline $\begin{array}{l}\text { Objective career success } \\
\text { in academia }\end{array}$ & Sub-categories generated from the data & $\begin{array}{l}\text { Subjective career success } \\
\text { in academia }\end{array}$ & Sub-categories generated from the data \\
\hline \multirow[t]{2}{*}{ Research productivity } & $\begin{array}{l}\text { External grant funding } \\
\text { Number of publications and citations } \\
\text { Publishing in high profile journals/with } \\
\text { reputable publishing houses/presses }\end{array}$ & Life satisfaction & $\begin{array}{l}\text { Happiness } \\
\text { Balancing work, family and leisure } \\
\text { Keeping stress under control } \\
\text { Staying healthy }\end{array}$ \\
\hline & $\begin{array}{l}\text { Generating more postgraduate students } \\
\text { Launching a research programme/leading a } \\
\text { research team } \\
\text { First/last/sole authorship }\end{array}$ & Contribution to society & $\begin{array}{l}\text { Making a lasting contribution to human } \\
\text { knowledge } \\
\text { Influencing people's behaviour or thinking } \\
\text { Connecting with/changing the local community }\end{array}$ \\
\hline Promotion and tenure & $\begin{array}{l}\text { Early promotion or tenure } \\
\text { Meeting requirements in research, teaching } \\
\text { and service (all-rounder) } \\
\text { Promotion to professor/a personal chair }\end{array}$ & Freedom & $\begin{array}{l}\text { To choose one's own research direction } \\
\text { To work collectively not just individually } \\
\text { To buy-out teaching to focus on research } \\
\text { To do interdisciplinary work } \\
\text { To teach in one's speciality area/s }\end{array}$ \\
\hline \multirow[t]{2}{*}{ Status } & $\begin{array}{l}\text { Disciplinary reputation } \\
\text { International invitations to collaborate on } \\
\text { research } \\
\text { Working in a reputable university } \\
\text { Research and teaching awards } \\
\text { Being given departmental (or wider } \\
\text { university) responsibilities }\end{array}$ & Job satisfaction & $\begin{array}{l}\text { Feeling confident as a researcher and teacher } \\
\text { Receiving positive, unsolicited feedback on } \\
\text { teaching from students and colleagues } \\
\text { Maintaining balance in all academic roles } \\
\text { Building a research niche/moulding the field } \\
\text { Mentoring/inspiring colleagues }\end{array}$ \\
\hline & & Influencing students & Influencing postgraduate students' \\
\hline Teaching performance & $\begin{array}{l}\text { High student evaluation scores } \\
\text { Teaching large classes }\end{array}$ & & $\begin{array}{l}\text { opportunities } \\
\text { Challenging students' thinking } \\
\text { Inspiring indigenous and/or female students }\end{array}$ \\
\hline Salary & $\begin{array}{l}\text { Adequate salary important, but not a key } \\
\text { marker of success }\end{array}$ & & 'Grandparenting' as a supervisor \\
\hline
\end{tabular}


